\title{
Gljive povezane s truleži plodova pitomog kestena, s prvim nalazom Gnomoniopsis smithogilvyi u Hrvatskoj
}

\author{
Fungi associated with nut rot in sweet chestnut, with the first record of \\ Gnomoniopsis smithogilvyi in Croatia
}

D. Ivić, Adrijana Novak

\section{SAŽETAK}

Trulež plodova pitomog kestena uzrokovana parazitskim gljivama može predstavljati značajan problem u plantažnoj proizvodnji te kulture. Tijekom 2018. godine, jaka pojava truleži plodova kestena zabilježena je u mješovitoj plantaži pitomog kestena i oraha u okolici Našica. U nasadu je sakupljeno 78 plodova (sorte Bouche de Betizac, Marsol i Maraval), među kojima su laboratorijskim pregledom u njih 63 utvrđeni simptomi truleži jezgre. Iz svih simptomatičnih plodova izolirane su gljive. Kombiniranom identifikacijom na temelju morfologije $i$ analize sekvenci ITS1-5.8S-ITS2 ribosomske DNA, gljive iz simptomatičnih plodova determinirane su kao Gnomoniopsis smithogilvyi, Neofusicoccum parvum, Botryosphaeria dothidea, Diaporthe eres i Fusarium proliferatum. Vrsta G. smithogilvyi utvrđena je u 47 od 63 ploda (75\%), nakon koje su po zastupljenosti slijedile $B$. dothidea (11/63 ploda, $17 \%$ ), N. parvum (10/63 ploda, $16 \%)$, D. eres (3/63 ploda, $5 \%$ ) i Fusarium sp. (1/63 ploda, $1,6 \%$ ). U 45 plodova utvrđena je samo jedna vrsta gljive, po dvije vrste nađene su u 11 plodova, a po tri vrste gljive u sedam plodova. Sve gljive utvrđene su na plodovima pitomog kestena u Hrvatskoj po prvi puta. Među njima ističe se prvi nalaz G. smithogilvyi, patogena koji u proteklih nekoliko godina uzrokuje velike štete na plodovima kestena u Europi.

Ključne riječi: Castanea sativa Mill., Gnomoniopsis smithogilvyi, trulež plodova

\section{ABSTRACT}

Nut rot caused by pathogenic fungi can represent a significant problem in sweet chestnut production. During 2018, a severe occurrence of nut rot in sweet chestnut was recorded in a mixed chestnut-walnut orchard near Našice in Eastern Croatia. Seventyeight nuts (cvs. Bouche de Betizac, Marsol and Maraval) were collected and inspected in laboratory. Rot symptoms were detected in 63 nuts. Fungi were isolated from all symptomatic nuts. By combining morphological identification and analysis of ITS15.8S-ITS2 ribosomal DNA sequences, fungi were identified as Gnomoniopsis smithogilvyi, Neofusicoccum parvum, Botryosphaeria dothidea, Diaporthe eres and Fusarium proliferatum. Species G. smithogilvyi was found in the highest incidence, in 47 out of 63 nuts ( $75 \%$ ), followed by B. dothidea (11/63 nuts, $17 \%)$, N. parvum (10/63 
D. Ivić i Adrijana Novak: Gljive povezane s truleži plodova pitomog kestena, s prvim nalazom Gnomoniopsis smithogolvyi u Hrvatskoj

nuts, $16 \%)$, D. eres (3/63 nuts, $5 \%$ ) and Fusarium sp. (1/63 nuts, $1.6 \%)$. A single fungal species was recorded in 45 nuts, while mixed infections of two species or three species were recorded in 11 and seven nuts, respectively. All fungi were found on sweet chestnut for the first time in Croatia. A record of G. smithogilvyi is especially relevant, as this species has been reported to have caused extensive damage in sweet chestnut production in Europe in the last years.

Key words: Castanea sativa Mill., Gnomoniopsis smithogilvyi, trulež plodova

\section{UVOD}

U Hrvatskoj se tijekom proteklih nekoliko godina javilo zanimanje za podizanje plantaža i plantažni uzgoj pitomog kestena (Castanea sativa Mill.). Glavni razlozi takvog interesa su potražnja za plodovima na tržištu i njihova relativno visoka otkupna cijena. Usto, odluku za ulazak u ulaganje s ciljem podizanja plantaže kestena danas potiče dostupnost većeg broja novih sorata, selekcioniranih na visoku rodnost i otpornost prema bolestima i štetnicima te dostupnost informacija o tehnologiji uzgoja (Prgomet i sur., 2013).

Pitomi kesten kao šumska vrsta, ali i kao voćarska kultura u proteklih je 80ak godina dva puta bio ugrožen zbog invazije stranih štetnih organizama u Europu. Rak kore (Cryphonectria parasitica (Murr.) Barr.) uzrokovao je velike štete u prirodnom arealu raširenosti pitomog kestena (Rigling i Prospero, 2018; Cvjetković, 2010.). Od početka novog stoljeća, Europom se širi kestenova osa šikarica, Dryocosmus kuriphilus Yasumatsu (Hymenoptera: Cynipidae) (Prgomet i sur., 2013.). Iako ne uzrokuje propadanje stabla, napad ose šiškarice štetan je u prirodnim šumskim sastojinama kestena, na zelenim javnim površinama i u plantažnim nasadima. Ipak, moguće je reći da je potencijalni rizik od navedenih organizama u proizvodnji pitomog kestena općenito $u$ opadanju. Štetnost gljive $C$. parasitica ublažena je širenjem mikovirusa Cryphonectria hypovirus 1 (ChV-1), koji uzrokuje smanjenje virulentnosti u populacijama C. parasitica (Rigling i Prospero, 2018; Krstin i sur., 2017). Uspjeh u kontroli D. kuriphilus pokazala je introdukcija parazitske osice Torymus sinensis Kamijo (Hymenoptera: Torymidae), parazitoida kestenove ose šiškarice (Matošević i sur., 2014; Prgomet i sur., 2013.). Osim toga, nove sorte kestena za plantažni uzgoj nerijetko su manje osjetljive ili relativno otporne na rak kore i na osu šiškaricu (Prgomet i sur., 2013.).

Od početka posljednjeg desetljeća, u Europi je došlo do pojave nove, relativno nepoznate bolesti pitomog kestena. Riječ je o truleži plodova koju 
D. Ivić i Adrijana Novak: Gljive povezane s truleži plodova pitomog kestena, s prvim nalazom Gnomoniopsis smithogolvyi u Hrvatskoj

uzrokuje gljiva Gnomoniopsis smithogilvyi L.A. Shuttlew., E.C.Y. Liev \& D.I. Guest, opisana i pod sinonimom Gnomoniopsis castaneae Tamietti. Pojava truleži plodova javila se u mješovitom plantažnom nasadu pitomog kestena $i$ oraha u okolici Našica. Prema navodima vlasnika, trulež plodova u jačem intenzitetu javlja se već tri godine, no tijekom 2018. godine javila se u tolikom postotku da je većina uroda propala. Opis simptoma odgovarao je opisu truleži plodova kestena koju uzrokuju parazitske gljive. Simptomatični plodovi su sakupljeni i dostavljeni na analizu u Zavod za zaštitu bilja, Hrvatski centar za poljoprivredu, hranu i selo. Kako su podaci o bolestima plodova pitomog kestena u Hrvatskoj vrlo oskudni, cilj rada bio je izolirati i analizirati gljive iz trulih plodova te dobiti saznanja o potencijalnim uzročnicima propadanja.

\section{MATERIJALI I METODE}

U nasadu je ukupno sakupljeno 78 plodova sorata Bouche de Betizac, Marsol i Marval (križanci C. sativa x Castanea crenata Siebold \& Zucc.) koji su dostavljeni u laboratorij. Plodovi su ispirani u tekućoj vodi nekoliko minuta, nakon čega su prerezani na pola kako bi se pregledala unutrašnjost jezgre. $\mathrm{Na}$ temelju simptoma u jezgri, plodovi su podijeljeni u dvije skupine, plodovi zahvaćeni smeđom truleži i plodovi zahvaćeni crnom truleži. Pola od prerezanih polovica plodova površinski je sterilizirano u etanolu (70 \%) kroz 30 sekundi, isprano u sterilnoj vodi te osušeno pod strujom zraka. Dijelovi simptomatičnih jezgara promjera oko $5 \mathrm{~mm}$ izrezani su skalpelom, postavljeni na krumpirdekstrozni agar (KDA) te inkubirani sedam do deset dana na režimu $20{ }^{\circ} \mathrm{C} / 25$ ${ }^{\circ} \mathrm{C}, 12 \mathrm{~h}$ tama/12h svijetlo. Drugi dio razrezanih polovica plodova postavljen je u vlažnu komoru i inkubiran kroz pet do sedam dana na sobnoj temperaturi kako bi se na njima eventualno javila sporulacija ili razvila plodišta gljiva. Svakom dijelu ploda inokuliranom na KDA i onom inkubiranom u vlažnoj komori dodana je identična oznaka kako bi se nakon inkubacije usporedile razvijene gljive.

Nakon inkubacije na KDA razvijene kulture gljiva su analizirane na temelju morfologije, preliminarno svrstane u četiri skupine (Botryosphaeriaceae, Phomopsis sp., Gnomoniopsis sp., Fusarium sp.), nakon čega je dio njih precijepljen na KDA u čistu kulturu s ruba rastućih kolonija. U isto vrijeme pregledane su polovice plodova inkubirane u vlažnoj komori te je uspoređena morfologija gljiva razvijenih na plodovima i onih razvijenih u kulturi. Čiste kulture na KDA inkubirane su 14 dana na istom režimu kao prethodno opisanom. Nakon inkubacije izolati su analizirani na temelju morfologije. Kako je kod svih izolata došlo do sporulacije, u obzir su uzeti rast, boja i izgled 
D. Ivić i Adrijana Novak: Gljive povezane s truleži plodova pitomog kestena, s prvim nalazom Gnomoniopsis smithogolvyi u Hrvatskoj

kolonije, izgled i prisutnost zračnog micelija te mjesto nastanka, boja, dimenzije i morfologija konidija. Za identifikaciju korišteni su opisi Udayangea i sur. (2014.), Phillipsa i sur. (2013.), Shuttlewortha i sur. (2012.) te Visentina i sur. (2012.). Na temelju morfologije, među izolatima utvrđeno je pet vrsta gljiva, Gnomoniopsis smithogilvyi, Botryosphaeria sp., Neofusicoccum sp., Phomopsis sp. i Fusarium proliferatum. U svrhu potvrde identifikacije, odabrana su po dva izolata identificirana kao G. smithogilvyi (KG4/18 i KG8/18), dva izolata identificirana kao Botryosphaeria sp. (KB1/18 i KB 5/18) te po jedan izolat identificiran kao Neofusicoccum sp. (KN1/18) i Phomopsis sp. (KP2/18) te je provedena analiza njihovih sekvenci ITS1-5.8S-ITS2 regije ribosomske DNA. Ukupna DNA iz kultura izolirana je iz micelija usitnjenog tekućim dušikom uz korištenje kompleta DNEasy Plant Mini Kit ${ }^{\circledR}$ (Quiagen Inc., SAD) prema uputama proizvođača. Ekstrakti DNA korišteni su u PCR reakciji $\left(94{ }^{\circ} \mathrm{C} / 2 \mathrm{~min}\right.$, 35 ciklusa $\left.94{ }^{\circ} \mathrm{C} / 30 \mathrm{~s}-55{ }^{\circ} \mathrm{C} / 30 \mathrm{~s}-72{ }^{\circ} \mathrm{C} / 1 \mathrm{~min}, 72{ }^{\circ} \mathrm{C} 10 \mathrm{~min}\right) \mathrm{s}$ parom početnica ITS1/ITS4 (White i sur., 1990), u reakcijskoj smjesi GoTaq ${ }^{\circledR}$ Master Mix (Promega Corp., SAD) prema uputama proizvođača. Produkti PCR reakcije su očitani na $1 \%$ agaroznom gelu, pripremljeni i poslani na sekvenciranje (Macrogen Europe, Amsterdam, Nizozemska). Dobivene sekvence uređene su u programu Sequencher ${ }^{\circledR}$ (Gene Codes Corporation, SAD) te uspoređene sa sekvencama u GenBank ${ }^{\circledR}$ bazi podataka, na temelju čega je za svaki izolat potvrđena ili određena vrsta kojoj pripada. Morfologija reprezentativnih sekvenciranih izolata uspoređena je s morfologijom ostalih izolata te je svaki izolat determiniran do razine vrste.

\section{REZULTATI I RASPRAVA}

Od ukupno 78 plodova, simptomi truleži jezgre utvrđeni su u njih 63. U 45 plodova utvrđena je samo jedna vrsta gljive. U 18 plodova utvrđena je mješovita zaraza, to jest prisutnost dvije vrste gljiva (11 plodova) ili tri vrste gljiva (sedam plodova).

Gljiva koja je u najvećem postotku izolirana iz trulih plodova (47/63 ploda, $75 \%)$ identificirana je kao Gnomoniopsis smithogilvyi. Deset izolata G. smithogilvyi uzgojeno u čistim kulturama na KDA razvilo je nakon 14 dana inkubacije na KDA bjeličasto-smeđe kolonije ispunjenje obiljem konidioma u vidu bjeličastih kapljica, naročito gustih oko središta inokulacije. Konidije izolata bile su jednostanične, bezbojne, izduženo-elipsoidne, prosječne duljine $7,0 \mu \mathrm{m}(5,1-7,2 \mu \mathrm{m})$ širine $2,9 \mu \mathrm{m}(2,5-3,1 \mu \mathrm{m})$. Morfologija izolata odgovarala je opisima G. smithogilvyi koje daju Shuttleworth i sur. (2012) te 
D. Ivić i Adrijana Novak: Gljive povezane s truleži plodova pitomog kestena, s prvim nalazom Gnomoniopsis smithogolvyi u Hrvatskoj

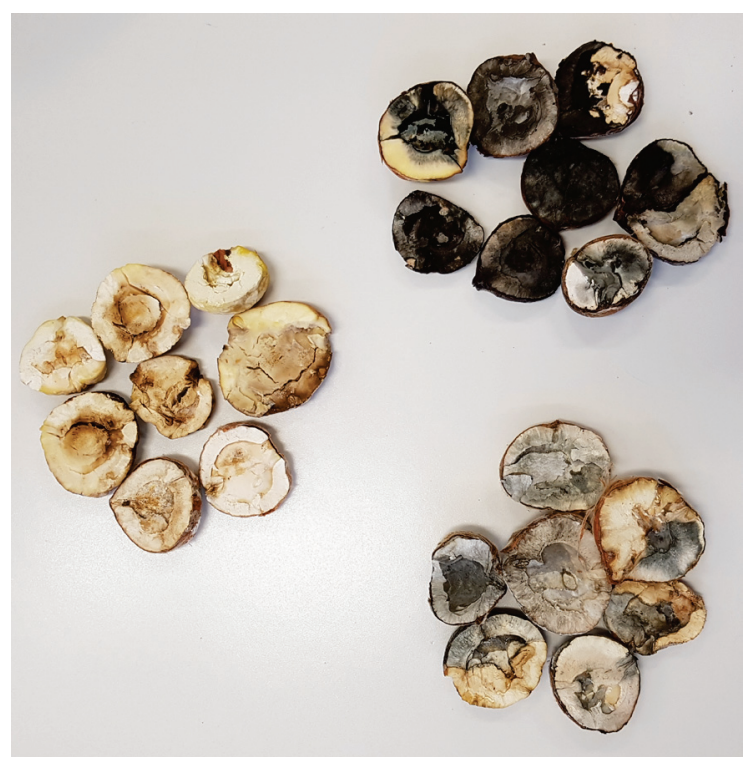

Slika 1. Plodovi kestena zahvaćeni s truleži. Iz crnih i sivih zona (gore desno i dolje desno) izolirane su uvijek i isključivo Botryosphaeria dothidea ili Neofusicoccum parvum, dok je iz smeđih, žutih ili bjeličastih zona (sredina lijevo) izoliran Gnomoniopsis smithogilvyi.

Picture 1 Sweet chestnut fruits affected with nut rot. Only Botryosphaeria dothidea or Neofusicoccum parvum were regularly isolated from black or grey rot (right), while Gnomoniopsis smithogilvyi was isolated from brown, yellow or whitish rot (left).

Visentin i sur. (2012). Sekvence ITS1-5.8S-ITS2 regije ribosomske DNA dvaju odabranih izolata (KG4/18 i KG8/18) pokazale su $99 \%$ sličnosti sa sekvencom G. smithogilvyi CBS 130190, holotipom vrste (Acc. MH865807) te s ostalim sekvencama $G$. smithogilvyi ili $G$. castaneae pohranjenima u GenBank ${ }^{\circledR}$ bazu podataka.

Nakon vrste G. smithogilvyi, druga i treća gljiva po učestalosti izolacije iz trulih plodova bile su vrste iz porodice Botryosphaeriaceae, Botryosphaeria dothidea (Moug. Ex Fr.) Ces \& de Not. (11/63 ploda, 17 \%) i Neofusicoccum parvum (Pennycook \& Samuels) Crous, Slippers \& A.J.L. Phillips (10/63 ploda, $16 \%$ ). Obje gljive stvarale su obilje piknida na plodovima oraha inkubiranima $u$ vlažnoj komori te manji broj piknida u kulturama na KDA. Morfologija svih izolata odgovarala je opisima vrsta (Phillips i sur., 2013). Sekvence ITS1-5.8SITS2 regije ribosomske DNA odabranih izolata (KB1/18, KB5/18 i KN1/18) 
D. Ivić i Adrijana Novak: Gljive povezane s truleži plodova pitomog kestena, s prvim nalazom Gnomoniopsis smithogolvyi u Hrvatskoj

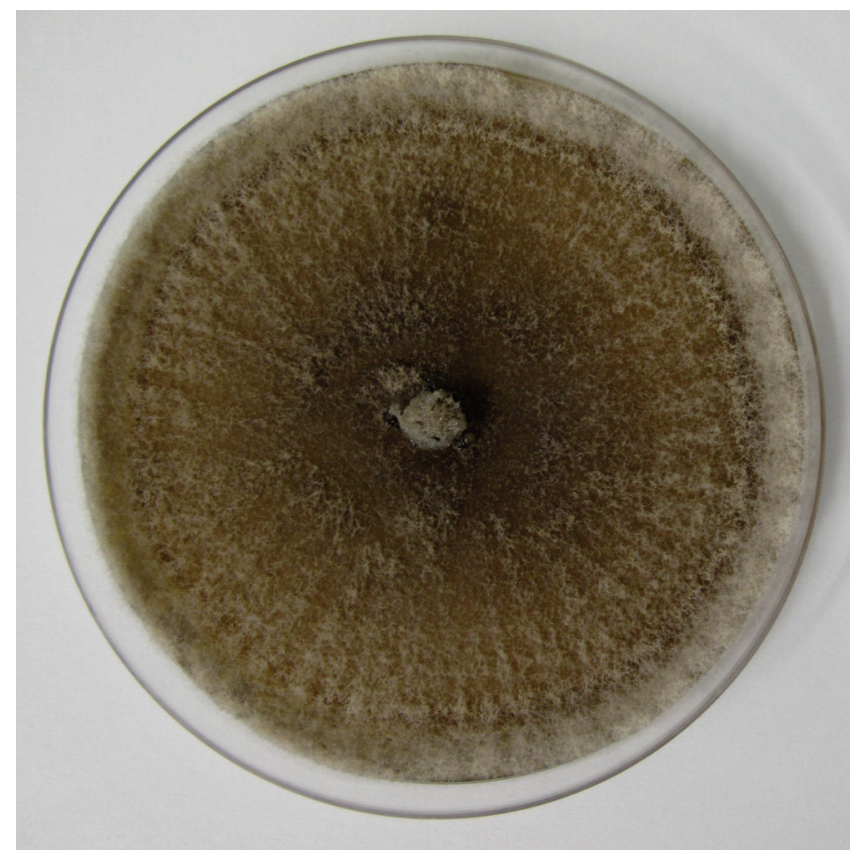

Slika 2. Gnomoniopsis smithogilvyi KG4/18 u kulturi na KDA nakon dva tjedna inkubacije.

Picture 2 Gnomoniopsis smithogilvyi KG4/18 culture on PDA after two weeks incubation.

pokazale su najviše sličnosti (99 \%) s više od 20 sekvenci upisanih u GenBank ${ }^{\circledR}$ bazu kao B. dothidea i N. parvum.

Tri izolata nađena samo u mješovitim zarazama ( $5 \%$ plodova) identificirana su kao Diaporthe eres Nitschke. Na KDA izolati su stvarali prljavo-bijeli vunasti micelij tipičan za gljive iz kompleksa Diaporthe/Phomopsis, boja kolonije s donje strane nakon 10 dana bila je smeđa, a u kulturama i na plodovima inkubiranima u vlažnoj komori stvaralo se obilje piknida. Sekvenca ITS1-5.8S-ITS2 regije ribosomske DNA izolata KP2/18 pokazala je $99 \%$ sličnosti s više od 20 sekvenci $D$. eres u GenBank ${ }^{\circledR}$ bazi podataka.

Iz simptomatičnih plodova kestena izolirane su gljive koje se navode kao patogene na kestenu ili na brojnim drugim drvenastim biljnim vrstama (Marsberg i sur., 2017; Dennert i sur., 2015; Udayanga i sur., 2014; Shuttleworth i sur., 2012.). Među njima, B. dothidea i N. parvum ističu se vrlo širokim krugom domaćina, među kojima je velik broj drvenastih voćarskih kultura (Mersberg i sur., 2017; Phillips i sur., 2013.). U Hrvatskoj su obje vrste 
D. Ivić i Adrijana Novak: Gljive povezane s truleži plodova pitomog kestena, s prvim nalazom Gnomoniopsis smithogolvyi u Hrvatskoj

nađene i potvrđene kao patogene na vinovoj lozi i na orahu (Ivić i sur., 2018; Kaliterna i Miličević, 2012.). Ipak, dominantna vrsta izolirana iz trulih plodova oraha bila je G. smithogilvyi. Gljiva G. smithogilvyi opisana je kao nova vrsta i uzročnik truleži plodova pitomog kestena i križanaca pitomog kestena i japanskog kestena (C. crenata $\mathrm{x} C$. sativa) u Australiji 2012. godine (Shuttleworth i sur., 2012.). Iste godine, u Europi je opisana je nova vrsta istog roda, Gnomoniopsis castaneae, kao uzročnik truleži plodova pitomog kestena u Francuskoj, Italiji, Švicarskoj i Novom Zelandu (Visentin i sur., 2012.). Usporedbom tih dvaju taksona, utvrđeno je da je riječ o istim vrstama te da ime G. smithogilvyi ima prednost i uzima se kao važeće (Shuttleworth i sur., 2015.).

Gljiva G. smithogilvyi postala je predmet interesa fitopatologa tijekom posljednjih nekoliko godina, ponajprije zato jer se širom Europe i u nekim drugim područjima svijeta sve češće bilježe velike štete u proizvodnji plodova pitomog kestena (Dennert i sur., 2015; Maresi i sur., 2013; Visentin i sur., 2012.). Štete preko $40 \%$ zabilježene su ne nekim lokacijama u Švicarskoj (Dennert i sur., 2015.), dok je u Australiji u nekim voćnjacima zabilježen postotak trulih plodva preko $70 \%$ (Shuttleworth i sur., 2013.). Situacija je postala osobito alarmantna u Italiji tijekom posljednje tri godine, kad je prema navodima iz pojedinih medija propalo do $80 \%$ plodova kestena u nekim područjima (Camoirano, 2016; Carfagno, 2018; Italiafruit News, 2018.). Biologija G. smithogilvyi još se istražuje. Utvrđeno je da gljiva živi kao endofit u granama, listovima i nezrelim plodovima (Visentin i sur., 2012), a pretpostavlja se da preživljava u biljnim ostacima te da do zaraze dolazi askosporama u doba cvatnje (Shuttleworth i sur., 2013.). Gljiva je nađena i u nekrotiziranim galama kestenove ose šiškarice (D. kuriphilus), no interakcija između G. smithogilvyi i ose šiškarice još uvijek je nerazjašnjena (Seddaiu i sur., 2017.).

Mjere zaštite protiv truleži plodova pitomog kestena su ograničene iz više razloga. Endofitska priroda gljive G. smithogilvyi i nepoznanice vezane uz biologiju patogena otežavaju osmišljavanje direktnih mjera. Uzgoj pitomog kestena u okviru ekološke proizvodnje ograničava eventualnu mogućnost kemijske zaštite, a proizvođači često ne raspolažu pogonima u kojima bi se plodovi nakon berbe tretirali vrućom ili hladnom vodom ili skladištili u kontroliranoj atmosferi (Vai i Bariselli, 2013.). Trulež plodova uzrokovana gljivom G. smitogilvyi može predstavljati značajan rizik za širenje plantažnog uzgoja pitomog kestena kao voćarske kulture u Hrvatskoj. 
D. Ivić i Adrijana Novak: Gljive povezane s truleži plodova pitomog kestena, s prvim nalazom Gnomoniopsis smithogolvyi u Hrvatskoj

\section{LITERATURA}

CAMOIRANO, M. (2016.): Dopo il cinipide, un fungo ora minaccia le castagne. La Stampa Savona, 1. srpnja 2016.

CARFAGNO, L.S. (2018.): La castagna in Montella in pericolo per un fungo, Pd: legge speciale o scomparirà. Le impresse: fatte presto. Nuova Irpinia, 9. listopada 2018.

CVJETKOVIĆ, B. (2010.): Mikoze i pseudomikoze voćaka i vinove loze. Zrinski, Čakovec.

DENNERT, F.G., BROGGINI, G.A.L., GESSLER, C., STORARI, M. (2015). Gnomoniopsis castanea is the main agent of chestnut nut rot in Switzerland. Phytopathologia Mediterranea 54: 199-211.

ITALIAFRUIT NEWS (2018.): Castagne, „Gnomoniopsis“ fa danni anche in Basilicata. ItaliaFruit News, 10. listopada 2018.

IVIĆ, D., NOVAK, A., KALITERNA, J., TOMIĆ, Ž. (2018.): Gljivični i pseudogljivični rak oraha u Hrvatskoj. Zbornik sažetaka 13. znanstvenostručnog savjetovanja hrvatskih voćara s međunarodnim sudjelovanjem, Daruvar, 1-3. ožujka 2108.

KALITERNA, J., MILIČEVIĆ, T. (2012.): Identification and pathogenicity of Botryosphaeriaceae species isolated from grapevines in Croatia. Proceedings of 8th International Workshop on Grapevine Trunk Diseases, Valencija, Španjolska, 18.-21. lipnja 2012.

KRSTIN, LJ., KATANIĆ, Z., JEŽIĆ, M., POLJAK, I., NUSKERN, L., MATKOVIĆ, I., IDŽOJTIĆ, M., ĆURKOVIĆ-PERICA, M. (2017.): Biological control of chestnut blight in Croatia: an interaction between host sweet chestnut, its pathogen Cryphonectria parasitica and the biological agent Cryphonectria hypovirus 1. Pest Management Science 73: 582-589.

MARESI, G., OLIVEIRA LONGA, C.M., TURCHETTI, T. (2013.): Brow rot on nuts of Castanea sativa Mill.: an emerging disease and its causal agent. iForest - Biogeosciences and Forestry 6: 294-301.

MARSBERG, A., KEMLER, M., JAMI, F., NAGEL, J.H., POSTMA-SMIDT, A., NAIDOO, S., WINGFIELD, M.J., CROUS, P.W., SPATAFORA, J.W., HESSE, C.N., ROBBERTSE, B., SLIPPERS, B. (2017.): Botryosphaeria dothidea: a latent pathogen of global importance to woody plant health. Molecular Plant Pathology 18: 477-488. 
D. Ivić i Adrijana Novak: Gljive povezane s truleži plodova pitomog kestena, s prvim nalazom Gnomoniopsis smithogolvyi u Hrvatskoj

MATOŠEVIĆ, D., QUACCHIA, A., KRISTON, É., MELIKA, G. (2014.): Biological control of the invasive Dryocosmus kuriphilus (Hymenoptera: Cynipidae) - an overview and the first trials in Croatia. South-east European Forestry 5: 3-12.

PHILliPS, A.J.L., ALVES, A., ABDOLLAHZADEH, J., SLIPPERS, B., WINGFIELD, M.J., GROENEWALD, J.Z., CROUS, P.W. (2013.): The Botryosphaeriaceae: genera and species known from culture. Studies in Mycology 76: 51-167.

PRGOMET, Ž., PRGOMET, I., BRANA, S. (2013.). Pitomi kesten (Castanea sativa Mill.). Skink d.o.o., Rovinj.

RIGLING, D., PROSPERO, S. (2018.): Cryphonectria parasitica, the causal agent of chestnut blight: invasion history, population biology and disease control. Molecular Plant Pathology 19: 7-20.

SEDDAIU, S., CERBONESCHI, A., SECHI, C., MELlO, A. (2017.): Gnomoniopsis castaneae associated with Dryocosmus kuriphilus galls in chestnut stands in Sardinia (Italy). iForest - Biogeosciences and Forestry 10: 440-445.

SHUTTLEWORTH, L.A., GUEST, D.I., LIEW, E.C.Y. (2012.): Fungal Planet description sheet 108: Gnomoniopsis smithogilvyi L.A. Shuttleworht, E.C.Y Liew \& D.I. Guest, sp. nov. Persoonia 28: 142-143.

SHUTTLEWORTH, L.A., LIEW, E.C.Y., GUEST, D.I. (2013.): Survey of the incidence of chestnut rot in south-eastern Australia. Australasian Plant Pathology 42: 63-72.

UDAYANGA, D., CASTELBURY, L.A., ROSSMAN, A.Y., CHUKEATIROTE, E., HYDE, K.D. (2014.): Insights into the genus Diaporthe: phylogenetic species delimitation in the $D$. eres species complex. Fungal Diversity 67: 203-229.

VAI, N., BARISELLI, M. (2013.): Raccolta penalizzata da insetti e funghi patogeni. In: La gestione biologica del castagno da frutto, I supplementi di Agricoltura 54 (Vai, N., Apruzzese, A., eds.), pp. 15-23.

VISENTIN, I., GENTILE, S., VALENTINO D., GONTHIER, P., TAMIETTI, G., CARDINALE, F. (2012): Gnomoniopsis castanea (sic) sp. nov. (Gnomoniaceae, Diaporthales) as a causal agent of nut rot of sweet chestnut. Journal of Plant Pathology 94: 411-419. 
D. Ivić i Adrijana Novak: Gljive povezane s truleži plodova pitomog kestena, s prvim nalazom Gnomoniopsis smithogolvyi u Hrvatskoj

WHITE, T.J., BRUNS, T., LEE, S., TAYLOR, J.W. (1990.): Amplification and direct sequencing of fungal ribosomal RNA genes for phylogenetics. In: PCR protocols: A guide to methods and applications (Innis, M.A., Gelfand, D.H., Sninsky, J.J., White, T.J., eds.), New York, Academic Press Inc., pp. 315-322.

\section{Adresa autora - Authors addresses:}

dr. sc. Dario Ivić,

e-mail: dario.ivic@hapih.hr

dr. sc. Adrijana Novak

Hrvatska agencija za poljoprivredu i hranu, Centar za zaštitu bilja,

Gorice 68b, Zagreb 